\title{
Infracommunities of Streblidae and Nycteribiidae (Diptera) on bats in an ecotone area between Cerrado and Atlantic Forest in the state of Mato Grosso do Sul
}

\author{
Guilherme D. P. Dornelles, Gustavo Graciolli, Anderson Odon \& Marcelo O. Bordignon \\ Laboratório de Zoologia, Instituto de Biociências, Programa de Pós-Graduação em Biologia Animal \\ Universidade Federal de Mato Grosso do Sul, Cidade Universitária, 79002-900 Campo Grande, MS, Brazil. (dornelles_d@hotmail.com)
}

\author{
Received 4 May 2017 \\ Accepted 10 November 2017
}

DOI: $10.1590 / 1678-4766 e 2017044$

\begin{abstract}
We described infracommunities, prevalence and mean intensity of infestation of ecotoparasite flies (Nycteribiidae and Streblidae) on bats in an ecotone area of Cerrado as predominant vegetation, with influence of Atlantic Forest, in the southeast of Mato Grosso do Sul. In 36 sampling nights between April 2015 and August 2016 (23,328 m².h), we captured 17 bat species, of which ten were infested, and 14 species of fly. The most abundant bats were the phyllostomids Artibeus planirostris (Spix, 1823), Glossophaga soricina (Pallas, 1776) and Carollia perspicillata (Linnaeus, 1758) and the most abundant flies were the streblids Trichobius longipes (Rudow, 1871), T. joblingi Wenzel, 1966 and Megistopoda aranea (Coquillett, 1899). Phyllostomus hastatus (Pallas, 1767) was the bat species that presented the highest infestation rate. Platyrrhinus lineatus (É. Geoffroy, 1810) and Desmodus rotundus (É. Geoffroy, 1810) were not infested. Besides that, the frequency of bats that were infested by a single species of fly was higher than the frequency of bats infested for two or more, and it may be a pattern.
\end{abstract}

KEYWORDS. Parasitology, Hippoboscoidea, Midwest.

RESUMO. Infacomunidades de Streblidae e Nycteribiidae (Diptera) em morcegos em uma área de ecótono entre Cerrado e Mata Atlântica no estado do Mato Grosso do Sul. Descrevemos infracomunidades, prevalência e intensidade média de infestação de moscas ectoparasitas (Nycteribiidae e Streblidae) sobre morcegos numa área de Cerrado como vegetação predominante, com influência de Mata Atlântica, no sudeste de Mato Grosso do Sul. Após 36 noites de coleta entre abril de 2015 e agosto de 2016 (23.328 $\left.\mathrm{m}^{2} . \mathrm{h}\right)$, capturamos 17 espécies de morcegos, das quais dez estavam infestadas, e 14 espécies de moscas. Os morcegos mais abundantes foram os filostomídeos Artibeus planirostris (Spix, 1823), Glossophaga soricina (Pallas, 1776) e Carollia perspicillata (Linnaeus, 1758) e as moscas mais abundantes foram as estréblidas Trichobius longipes (Rudow, 1871 ), T. joblingi Wenzel, 1966 e Megistopoda aranea (Coquillett, 1899). Phyllostomus hastatus (Pallas, 1767) foi a espécie de morcego que apresentou as taxas de infestação mais elevadas. Platyrrhinus lineatus (É. Geoffroy, 1810) e Desmodus rotundus (É. Geoffroy, 1810) não estavam infestados. Além disso, a frequência em que os morcegos estavam infestados por apenas uma espécie de mosca foi superior à dos que estavam infestados por duas ou mais, o que pode ser um padrão.

PALAVRAS-CHAVE. Parasitologia, Hippoboscoidea, Centro-Oeste.

Among mammals, bats represent 178 species distributed in nine families in Brazil, with Phyllostomidae as the most specious, with 92 valid species (NoGUEIRA et al., 2014). They have great ecological importance as maintainers of the insect population balance, pollinators and seed dispersers. Usually the bats are infested by hematophagous flies adapted and highly specific, classified in two families, Streblidae and Nycteribiidae, both exclusive bat parasites.

Streblidae consists of macropterous, brachypterous and apterous Diptera (Wenzel \& Peterson, 1987), while Nycteribiidae are all apterous (Peterson \& Wenzel, 1987). Both families are cosmopolitan and their distribution correlates with their hosts (WENZEL et al., 1966).

The streblid flies are divided into five subfamilies, Nycterophiliinae, Trichobiinae and Streblinae for the New World, and Brachytarsininae and Ascodipterinae for the Old World (DicK \& MiLLER, 2010), and the Nycteribiidae are distributed in three, Archinycteribiinae and Cyclopodiinae exclusive to the Old World and Nycteribiinae cosmopolitan, with two genus in the New World, Basilia MirandaRibeiro, 1903 and Hershkovitzia Guimarães e D'Andretta, 1956 (GRACIOLLI, 2010). For Brazil there are record of 80 Streblidae species (GRACIOLLI, 2017a) and 26 Nycteribiidae species (GRACIOLLI, 2017b).

There are few studies that describe the streblids and nicteribiids communities on their hosts through parasitological indexes in the cerrado (KOMENo \& LinHARES, 1999; AgUIAR \& ANTONINI, 2011; ERIKSSON et al., 2011; VASCONCELOS et al., 2016), and even fewer describe the infracommunities (SANTos et al., 2013; AgUiAR \& ANTONINI, 2016; BARBIER \& GRACIOLLI, 2016).

Seeking to contribute to the knowledge of possible patterns of parasitism between the ectoparasitic flies and their chiropteran hosts, the present study aimed to describe 
quantitatively the population of these Diptera, prevalence and mean intensity, besides recording the infracommunities in the southeast of Mato Grosso do Sul.

\section{MATERIAL AND METHODS}

The study was performed in the legal reserve of Fazenda Dona Amélia, 905 ha, in the city of Nova Andradina, Mato Grosso do Sul (22¹2’37.314”S 5328’35.576”W). The local vegetation is predominantly cerrado, with influences of Atlantic rainforest. The climate is Aw of Köppen, tropical humid with well-defined seasons. Annual precipitation fluctuates from 1,400 to $1,700 \mathrm{~mm}$, with mean temperature above $18^{\circ} \mathrm{C}$ in the coldest month (OliveIRA et al., 2000).

The bats were captured with mist nets, between April 2015 and August 2016, in spots distributed around the farm, aiming to capture the higher possible diversity. We used four $3 \times 9 \mathrm{~m}$ nets in the first six hours of the night, with 36 nights total, sampling effort of $23,328 \mathrm{~m}^{2}$.h (Tab. I) (STRAUBE \& BIANCONI, 2002). The nets were visited every 15 minutes and the captured bats were placed in cotton bags to later screening. We inspected the bats with the naked eye and collected the flies with trousers and placed in Eppendorf tubes with $70 \%$ alcohol.

The bats identification was performed in the field, when possible, with help of specific identification keys (Charles-Dominique et al., 2001; Gregorin \& TADDEI, 2002; ReIs et al., 2007; MiRANDA et al., 2011; ReIs et al., 2013). A male and a female of each bat specie and the individuals that could not be identified in the field were killed by cervical dislocation and deposited in the Coleção Zoológica de Referência da Universidade Federal de Mato Grosso do Sul (ZUFMS) under authorization of the Instituto Chico Mendes de Conservação da Biodiversidade (ICMBio) \#5064201, and under protocol \#728/2015 of the Comissão de Ética no Uso de Animais da Universidade Federal de Mato Grosso do Sul (CEUA/UFMS).

The flies were identified with a stereomicroscope in the Laboratório de Sistemática, Ecologia e Evolução (LSEE) of Universidade Federal de Mato Grosso do Sul. For Streblidae we used the genus key of Dick \& MiLleR (2010) and the specific keys of GUERRERo (1994a,b; 1995a,b; 1996; 1997), and for Nycteribiidae the key of GRACIOLLI (2004).
The flies are going to be deposited in the ZUFMS.

To calculate the prevalence $(\mathrm{P})$, percentage of bats infested by certain fly species, and mean intensity of infestation (MI), average number of individuals of a given species of fly in each infested bat, we utilized the software Quantitative Parasitology 3.0 (RózsA et al., 2000), utilizing $95 \%$ confidence rate to the intervals. We considered as accidental infestation the non-primary infestations $(\mathrm{P}<5 \%)$ (DICK, 2007) when the primary host of the dipteran was captured in the same night.

The description of the infracommunities and infrapopulations was compiled in a table considering only the species composition, not abundance. We excluded the quantitative analysis and the description of the infracommunities of the bat species with captures below $10(n<10)$ or that did not present ectoparasites.

\section{RESULTS}

We captured 452 bats of 17 species of four families, in order of abundance, Phyllostomidae $(\mathrm{n}=418)$, Vespertilionidae $(n=18)$, Molossidae $(n=14)$, and Noctilionidae $(n=2)$. Of these, we collected 519 flies, being 513 of 13 species of Streblidae, ten of Trichobiinae and three of Streblinae, and six dipterans of Basilia carteri Scott, 1936 (Nycteribiidae), total of 14 fly species. The most abundant bat was the phillostomid Artibeus planirostris (Spix, 1823) $(\mathrm{n}=126)$, and the most abundant fly was Trichobius longipes (Rudow, 1871) ( $\mathrm{n}=161)$ (Tab. II).

The total prevalence was $44.3 \%$ with mean intensity of infestation of 2.66 (Tab. II). Phyllostomus hastatus (Pallas, 1767) was the most infested bat species, as well as in prevalence as in intensity, associated to T. longipes, and Glossophaga soricina (Pallas, 1776) was the less infested species, associated to T. dugesii Townsend, 1891, when excluded accidental infestations.

A total of 18 compositions of fly species was found in the seven bat species analyzed (Tab. III). The bat species that presented the highest quantity of different parasites composition was $A$. planirostris, with three infracommunities that involved the three infrapopulations found. Glossophaga soricina, Myotis nigricans (Schinz, 1821) and P. hastatus showed only one infrapopulation composition.

Tab. I. Sample effort of studies that described bat ectoparasites (Streblidae and Nycteribiidae) communities in the Cerrado, Brazil.

\begin{tabular}{ccccc}
\hline State & Fly species & $\begin{array}{c}\text { Bats inspected } \\
\text { (total species })\end{array}$ & $\begin{array}{c}\text { Sampling effort } \\
\left(\mathrm{m}^{2} \mathrm{~h}\right)\end{array}$ & KoMENO \& LiNHARES, 1999 \\
MG & 12 & $205(12)$ & $\#$ & AGUIAR \& ANTONINI, 2011 \\
DF & 7 & $619(3)$ & 11289.60 & ERIKSSON et al., 2011 \\
MS & 17 & $327(13)$ & 129600 & SANTOS et al., 2013 \\
MA & 25 & $487(27)$ & 24300 & VASCONCELOS et al., 2015 \\
MG & 38 & $880(33)$ & 28080 & AGUIAR \& ANTONINI, 2016 \\
DF & 24 & $892(15)$ & 23328 & BARBIER \& GRACIOLLI, 2016 \\
MS & 22 & $708(22)$ & Present study \\
MS & 14 & $452(17)$ & &
\end{tabular}


Tab. II. Streblidae and Nycteribiidae fly species collected from bats in Fazenda Dona Amélia, Nova Andradina, state os Mato Grosso do Sul, Brazil (a, Accidental infestation; ${ }^{\text {b, }}$ Insuficient data to calcule coinfidence intervals).

\begin{tabular}{|c|c|c|c|c|c|}
\hline Host & $\mathrm{n}$ & Bat fly & $\mathrm{n}$ & $\mathrm{P}(95 \% \mathrm{CI})$ & MI $(95 \% \mathrm{CI})$ \\
\hline $\begin{array}{l}\text { Molossidae } \\
\text { Molossops temminckii (Burmeister, 1854) }\end{array}$ & 14 & - & & & \\
\hline $\begin{array}{l}\text { Noctilionidae } \\
\text { Noctilio albiventris Desmarest, } 1818\end{array}$ & 2 & $\begin{array}{l}\text { Paradyschiria parvula } \\
\text { Falcoz, } 1931\end{array}$ & 11 & & \\
\hline \multirow[t]{2}{*}{$\begin{array}{l}\text { Phyllostomidae } \\
\text { Artibeus lituratus (Olfers, 1818) }\end{array}$} & 43 & $\begin{array}{l}\text { Aspidoptera phyllostomatis } \\
(\text { Perty, } 1833)^{\mathrm{a}}\end{array}$ & 1 & $2,3(0.05-12.29)$ & $1^{\mathrm{b}}$ \\
\hline & & $\begin{array}{l}\text { Paratrichobius longicrus } \\
\text { (Ribeiro, 1907) }\end{array}$ & 14 & $20.9(10.04-36.05)$ & $1.56(1.11-2)$ \\
\hline \multirow[t]{3}{*}{ Artibeus planirostris (Spix, 1823) } & 126 & $\begin{array}{l}\text { Aspidoptera phyllostomatis } \\
\text { (Perty, 1833) }\end{array}$ & 42 & $19(12.60-27.01)$ & $1.63(1.29-2.21)$ \\
\hline & & $\begin{array}{l}\text { Megistopoda aranea } \\
\text { (Coquillett, 1899) }\end{array}$ & 93 & $34.9(26.64-43.93)$ & $2.09(1.70-2.59)$ \\
\hline & & $\begin{array}{l}\text { Metelasmus pseudopterus } \\
\text { Coquillett, } 1907\end{array}$ & 5 & $3.2(0.87-7.93)$ & $1.25(1-1.50)$ \\
\hline \multirow[t]{3}{*}{ Carollia perspicillata (Linnaeus, 1758) } & 69 & $\begin{array}{l}\text { Megistopoda aranea } \\
\text { (Coquillett, 1899) }^{\mathrm{a}}\end{array}$ & 1 & $1,4(0.03-7.82)$ & $1^{\mathrm{b}}$ \\
\hline & & $\begin{array}{c}\text { Strebla guajiro } \\
\text { (Garcia \& Casal, 1965) }\end{array}$ & 10 & $11,6(5.14-21.58)$ & $1.25(1-1.75)$ \\
\hline & & $\begin{array}{l}\text { Trichobius joblingi } \\
\quad \text { Wenzel, } 1966\end{array}$ & 116 & $66,7(54.28-77.57)$ & $3.24(2.63-3.89)$ \\
\hline Chrotopterus auritus (Peters, 1856) & 1 & - & & & \\
\hline Desmodus rotundus (É. Geoffroy, 1810) & 16 & - & & & \\
\hline Glossophaga soricina (Pallas, 1776) & 82 & $\begin{array}{l}\text { Trichobius dugesii } \\
\text { Townsend, } 1891\end{array}$ & 14 & $17.1(9.66-26.99)$ & $1^{\mathrm{b}}$ \\
\hline Lophostoma brasiliense (Peters, 1866) & 1 & $\begin{array}{l}\text { Strebla tonatiae } \\
\text { (Kessel, 1924) }\end{array}$ & 1 & & \\
\hline Micronycteris megalotis (Gray, 1842) & 4 & - & & & \\
\hline Phyllostomus discolor Wagner, 1843 & 1 & $\begin{array}{l}\text { Trichobius costalimai } \\
\quad \text { Guimarães, } 1938\end{array}$ & 14 & & \\
\hline Phyllostomus hastatus (Pallas, 1767) & 42 & $\begin{array}{l}\text { Trichobius longipes } \\
\quad \text { (Rudow, 1871) }\end{array}$ & 161 & $88.1(74.36-96.02)$ & $4.35(3.41-6.43)$ \\
\hline Platyrrhinus lineatus (É. Geoffroy, 1810) & 8 & - & & & \\
\hline \multirow[t]{3}{*}{ Sturnira lilium (É. Geoffroy, 1810) } & 25 & $\begin{array}{l}\text { Aspidoptera falcata } \\
\text { Wenzel, } 1976\end{array}$ & 21 & $36(17.97-57.48)$ & $2,33(1.33-3.56)$ \\
\hline & & $\begin{array}{l}\text { Megistopoda aranea } \\
\text { (Coquillett, 1899) }^{\mathrm{a}}\end{array}$ & 1 & $4(0.1-20.36)$ & $1^{\mathrm{b}}$ \\
\hline & & $\begin{array}{l}\text { Megistopoda proxima } \\
\quad \text { (Séguy, 1926) }\end{array}$ & 8 & $24(9.35-45.13)$ & $1.33(1-1.67)$ \\
\hline \multicolumn{6}{|l|}{ Vespertilionidae } \\
\hline Myotis nigricans (Schinz, 1821) & 15 & Basilia carteri Scott, 1936 & 6 & $26.7(7.78-55.11)$ & $1.5(1-2)$ \\
\hline Eptesicus furinalis (d'Orbigny \& Gervais, 1847) & 2 & - & & & \\
\hline Total & 452 & & 519 & $44.3(39.43-49.17)$ & $2.66(2.37-3.12)$ \\
\hline
\end{tabular}

Tab. III. Infrapopulations and infracommunities of flies on bats captured in Fazenda Dona Amélia, Nova Andradina, MS, Brazil.

\begin{tabular}{lcc}
\hline Host (n) & Infracommunity/Infrapopulation & Frequency \\
\hline Artibeus lituratus (10) & Aspidoptera phyllostomatis & 1 \\
& Paratrichobius longicrus & 9 \\
Artibeus planirostris (62) & Aspidoptera phyllostomatis & 15 \\
& Megistopoda aranea & 34 \\
& Metelasmus pseudopterus & 2 \\
\hline
\end{tabular}


Tab. III. Cont.

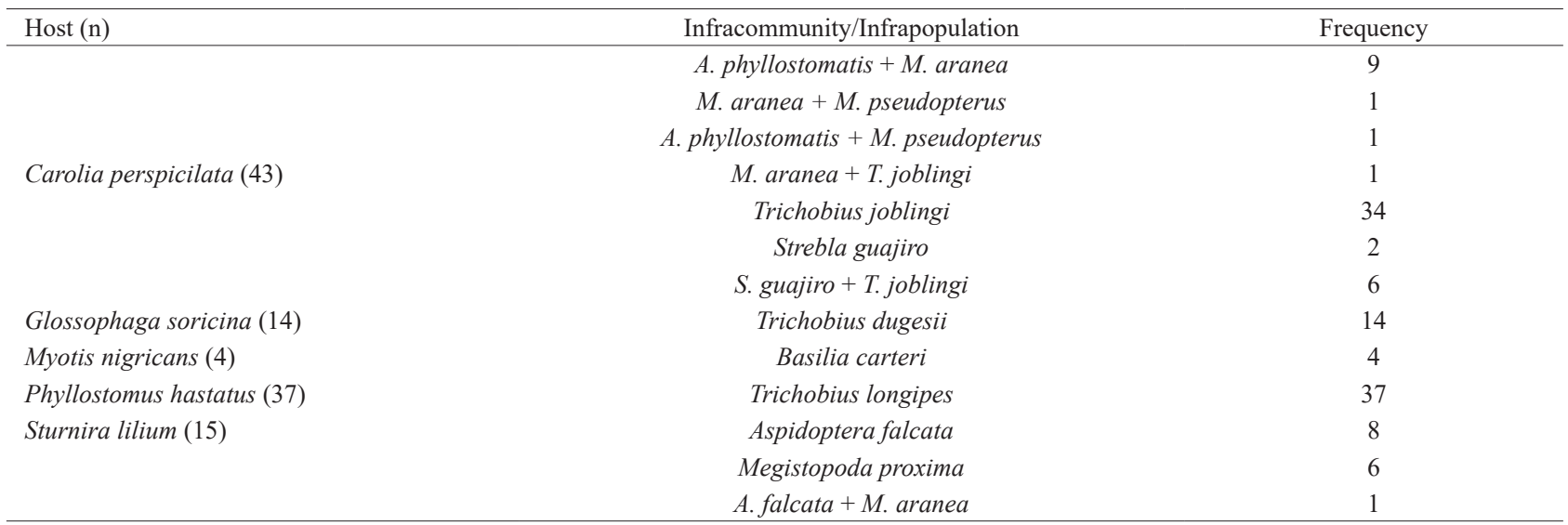

\section{DISCUSSION}

The number of fly species collected at the present study (14) was lower than in other studies in the same state, within the area of cerrado. ERIKSSON et al. (2011), even with about half of our sampling effort, found 17 fly species. BARBIER \& GRACIOLLI (2016), with sampling effort a little bigger $(28,080$ $\mathrm{m}^{2} . \mathrm{h}$ ), collected 22 species. In disagree with the works above-mentioned, the Desmodus rotundus (É. Geoffroy, 1810) and Platyrrhinus lineatus (É. Geoffroy, 1810) that we captured did not show infestation. In cerrado, D. rotundus is known for being host to Strebla wiedemanni Kolenati, 1856, Trichobius furmani Wenzel, 1966 and T. parasiticus Gervais, 1844 and P. lineatus host of Paratrichobius aff. longicrus (Miranda Ribeiro, 1907), P. sanchezi Wenzel, 1966 and T. cf. angulatusWenzel, 1976 (Graciolli et al., 2010; ERIKSSON et al., 2011; BARBIER \& GRACIOLLI, 2016; VASCONCELOS et al., 2016).

Artibeus lituratus (Olfers, 1818) was infested by $P$. longicrus, differently of what other works found out in the Cerrado (Komeno \& Linhares, 1999; Graciolli et al., 2010; ERIKSSON et al., 2011; SANTOS et al., 2013; FiguEIREDO et al., 2015; BARBIER \& GRACIOLLI, 2016), with exception of works in Goiás and Distrito Federal (CoIMBRA et al., 1983). In this domain, $P$. longicrus is usually associated to $P$. lineatus, being probably a different species from what occurs on Artibeus planirostris and A. lituratus (GRACIOLLI et al., 2010). It is presumed that we captured $A$. lituratus infested by $P$. longicrus due to the study area being in an ecotone of Cerrado and Atlantic rainforest, domain where this association is more common.

Noctilio albiventris Desmarest, 1818 was infested only by Paradyschiria parvula Falcoz, 1931, however, the number of captured bats was low for greater inferences. In Brazil, $N$. albiventris is a primary host to P. parvula, Noctiliostrebla maai Wenzel, 1966 and Xenotrichobius noctilionis (GUERRERO, 1995b).

The high prevalence $(\mathrm{P}>50 \%)$ of Trichobius joblingi Wenzel, 1966 on Carollia perspicillata (Linnaeus, 1758) and of T. longipes on Phyllostomus hastatus, as well as the low values ( $\mathrm{P}<5 \%$ ) of Metelasmus pseudopterus Coquillett, 1907 in Artibeus planirostris, may be a pattern to cerrado (Komeno \& LinHARES, 1999; ERIKSSON et al., 2011; SANTOS et al., 2013; BARBIER \& GRACIOLLI, 2016; VASCONCELOS et al., 2016).

Overall, very close values of all prevalence found in the present work has already been recorded in others in this dominion, except $P$. longicrus in $A$. lituratus, we found higher values, and $B$. carteri in $M$. nigricans, with no previous records of prevalence and mean intensity of this association.

The mean intensity of infestation that we registered of $T$. longipes on $P$. hastatus and P. longicrus on A. lituratus are the highest, until now, to Cerrado. Close values to the other intensities already registered in the previously-mentioned works.

We found higher frequencies of infrapopulations $(n=166)$ than infracommunities $(n=19)$ on the individuals hosts, setting a possible association pattern (BARBIER \& GRACIOLLI, 2016). Artibeus planirostris presented the highest number of composition of different parasite species $(n=6)$, without accidental infestations, differently from the other works in the Cerrado (SANTOS et al., 2013; BARBIER \& GRACIOLLI, 2016).

From the 18 compositions of association recorded, three originated from possible contaminations. Accidental associations can highly increase the number of infracommunities, not reflecting the nature of the data, what emphasizes greater care in the parasites collection.

Acknowledgements. We thank CAPES and FUNDECT by the financial assistance, and the owner and workers of Fazenda Dona Amélia by the logistical support. We thank Cynthia Mazzi for the English review.

\section{REFERENCES}

Aguiar, L. M. S. \& Antonini, Y. 2011. Descriptive ecology of bat flies (Diptera: Hippoboscoidea) associated with vampire bats (Chiroptera: Phyllostomidae) in the cerrado of Central Brazil. Memórias do Instituto Oswaldo Cruz 106(2):170-176. doi: 10.1590/s007402762011000200009.

Aguiar, L. M. S. \& Antonini, Y. 2016. Prevalence and intensity of Streblidae in bats from a Neotropical savanna region in Brazil. Folia Parasitologica 63:024.doi: 10.14411/fp.2016.024. 
Barbier, E. \& Graciolli, G. 2016. Community of bat flies (Streblidae and Nycteribiidae) on bats in the Cerrado of Central-West Brazil: hosts, aggregation, prevalence, infestation intensity, and infracommunities. Studies on Neotropical Fauna and Environment 51(3):1-12. doi: 10.1080/01650521.2016.1215042.

Charles-Dominique, P.; Brosset, A. \& Jouard, S. 2001. Les Chauvessouris de Guyane. Paris, Muséum national d'Histoirenaturelle. 176p.

Coimbra, C. E. A. JR.; Guimarães, L. R. \& Mello, D. A. 1983. Ocorrência de Streblidae (Diptera: Pupipara) em morcegos capturados em regiões do Cerrado do Brasil Central. Revista Brasileira de Entomologia 28(4):547-550.

Dick, C. W. 2007. High host specificity of obligate ectoparasites. Ecological Entomology 32:446-450. doi: 10.1111/j.1365-2311.2007.00836.x.

Dick, C. W. \& Miller, J. A. 2010.Streblidae (Bat Flies). In: Brown, B. V.; Borkent, A.; Cumming, J. M.; Wood, D. M.; Woodley N. E. \& Zumbado, M. eds. Manual of Central American Diptera Vol. 2. Ottawa, NRC Research Press, p. 1249-1260.

Eriksson, A.; Graciolli, G. \& Fischer, E. 2011.Bat flies on phyllostomid hosts in the Cerrado region: component community, prevalence and intensity of parasitism. Memórias do Instituto Oswaldo Cruz 106:274278. doi: 10.1590/s0074-02762011000300004.

Figueiredo, D.; Graciolli, G. \& Aguiar, L. M. S. 2015. New records of bat flies (Diptera, Streblidae and Nycteribiidae) in Cerrado of Central Brazil. Checklist 11(5):1-5. doi: 10.15560/11.5.1761.

Graciolli, G. 2004. Nycteribiidae (Diptera, Hippoboscoidea) no Sul do Brasil. Revista Brasileira de Zoologia 21(4):971-985. doi: 10.1590/ s0101-81752004000400035.

Graciolli, G. 2010. Nycteribiidae (Bat flies, spider bat flies). In: Brown, B. V.; Borkent, A.; Cumming, J. M.; Wood, D. M.; Woodley N. E. \& Zumbado, M. eds. Manual of Central American Diptera Vol. 2. Ottawa, NRC Research Press, p. 1261-1266.

Graciolli, G. 2017a. Streblidae in Catálogo Taxonômico da Fauna do Brasil. PNUD. Available at $<$ http://fauna.jbrj.gov.br/fauna/faunadobrasil/2624>. Accessed on 23 April 2017.

Graciolli, G. 2017b. Nycteribiidae in Catálogo Taxonômico da Fauna do Brasil. PNUD. Available at $<$ http://fauna.jbrj.gov.br/fauna/ faunadobrasil/2992>. Accessed on 23 April 2017.

Graciolli, G.; Zortéa, M. \& Carvalho, L. F. A. C. 2010. Bat flies (Diptera, Streblidae and Nycteribiidae) in a Cerrado area of Goiás State, Brazil. Revista Brasileira de Entomologia 54(3):511-514. doi: 10.1590/ S0085-56262010000300025.

Gregorin, R. \& TADDEI,V. A. 2002. Chave artificial para a identificação de molossídeos brasileiros (Chiroptera: Molossidae). Mastozoologia Neotropical 9(1):13-32.

Guerrero, R. 1994a. Catalogo de los Streblidae (Diptera: Pupipara) parasitos de murcielagos (Mammalia: Chiroptera) del nuevo mundo. IV. Trichobiinae con alas desarrolladas. Boletin de Entomologia Venezolana 9(2): 161-192.

Guerrero, R. 1994b. Catalogo de los Streblidae (Diptera: Pupipara) parasitos de murcielagos (Mammalia: Chiroptera) del nuevo mundo. II. Los grupos: pallidus, caecus, major, uniformis, y longipes del genero Trichobius Gervais, 1844. Acta Biologica Venezuelica 15(1):1-18.

Guerrero, R. 1995a. Catalogo de los Streblidae (Diptera: Pupipara) parasitos de murcielagos (Mammalia: Chiroptera) del nuevo mundo. III. Los grupos: dugesii, dunni y phyllostomae del genero Trichobius Gervais, 1844. Acta Biologica Venezuelica 15(3):1-27.
Guerrero, R. 1995b. Catalogo de los Streblidae (Diptera: Pupipara) parasitos de murcielagos (Mammalia: Chiroptera) del nuevo mundo. V. Trichobiinae con alas reducidas o ausentes y miscelaneos. Boletin de Entomologia Venezolana 10(2):135-160.

Guerrero, R. 1996. Catalogo de los Streblidae (Diptera: Pupipara) parasitos de murcielagos (Mammalia: Chiroptera) del nuevo mundo. VI. Streblinae. Acta Biologica Venezuelica 16(2):1-25.

Guerrero, R. 1997. Catalogo de los Streblidae (Diptera: Pupipara) parasitos de murcielagos (Mammalia: Chiroptera) del nuevo mundo. VII. Lista de especies, hospedadores y paises. Acta Biologica Venezuelica 17(1):9-24

Komeno, C. A. \& Linhares, A. X. 1999. Batflies parasitic on some phyllostomid bats in Southeastern Brazil: parasitism rates and hostparasite relationships. Memórias do Instituto Osvaldo Cruz 94(2):151156. doi: 10.1590/s0074-02761999000200004.

Miranda, J. M. D.; Bernardi, I. P. \& Passos F. C. 2011. Chave ilustrada para a determinação dos morcegos da Região Sul do Brasil. Curitiba, Universidade Federal do Paraná. 51p.

Nogueira, M. R.; Lima, I. P.; Moratelli, R.; Tavares, V. C., Gregorin, R. \& PERACCHI, A. L. 2014. Checklist of Brazilian bats, with comments on original records. Check list 10:808-821. doi: 10.15560/10.4.808.

Oliveira, H.; Urchei, M. A. \& Fietz, C. R. 2000. Aspectos físicos e socioeconômicos da bacia hidrográfica do rio Ivinhema. Dourados, Embrapa Agropecuária Oeste. 52p.

Peterson, B. V.\& Wenzel, R. L. 1987. Nycteribiidae. In: Mc Alpine, J. F.; Peterson, B. V.; Shewell, G. E.; Tekey, H. J.; Vockeroth, J. R. \&Wood, D. M. eds. Manual of Nearctic Diptera Vol. 2. Ottawa, Research Branch, Agriculture Canada, p. 1283-1291.

Reis, N. R.; Fregonezi, M. N.; Peracchi, A. L. \& Shibatta, A. O. 2013. Morcegos do Brasil: guia de campo. Rio de Janeiro, Technical Books. 252p.

Reis, N. R.; Peracchi, A. L.; Pedro, W. A. \& Lima, I. P. 2007. Morcegos do Brasil. Londrina, Nélio R. dos Reis. 253p.

Rózsa, L.; Reiczigel, J. \& MAJoros, G. 2000.Quantifying parasites in samples of hosts. Journal of Parasitology 86:228-232. doi: $10.2307 / 3284760$.

Santos, C. L. C.; Pereira, A. C. N.; Bastos, V. J. C.;Graciolli, G. \& RebÊLO, J. M. M. 2013. Parasitism of ectoparasitic flies on bats in the northern Brazilian cerrado. Acta Parasitologica 58(2):207-214. doi: 10.2478/s11686-013-0135-9.

Straube, F.C. \& Bianconi, G. V. 2002. Sobre a grandeza e a unidade utilizada para estimar esforço de captura com a utilização de redesde-neblina. Chiroptera Neotropical 8:150-152.

Vasconcelos, P. F.; Falcão, L. A. D.; Graciolli, G. \& Borges, M. 2016. Parasite-host interactions of bat flies (Diptera: Hippoboscoidea) in Brazilian tropical dry forests. Parasitology Research 115(1):367-377. doi: 10.1007/s00436-015-4757-8.

Wenzel, R. L. \& Peterson, B. V. 1987. Streblidae. In: Mc Alpine, J. F.; Peterson, B. V.; Shewell, G. E.; Tekey, H. J.; Vockeroth, J.R. \&Wood, D. M. eds. Manual of Nearctic Diptera Vol. 2. Ottawa, Research Branch, Agriculture Canada, p. 1293-1301.

Wenzel, R. L.; Tipton, V. J. \& Kiewliez, A. 1966. The streblid bat flies of Panama (Diptera: Calypterae: Streblidae). In: Wenzel, R. L. \& Tipton, V. J. eds. Ectoparasites of Panama. Chicago, Field Museum of Natural History, p. 405-675. 